\title{
Urban Landscape and Horror Vacui, spectacularity of a distorted perception.
}

\section{Giorgio Verdiani}

Dipartimento di Architettura, Università degli Studi di Firenze giorgio.verdiani@unifi.it

\section{Stéphane Giraudeau}

Dipartimento di Architettura, Università degli Studi di Firenze

stephane.giraudeau1@gmail.com

\begin{abstract}
In this article, the very original urban landscape perception caused by the emergency after the 2020' New Coronavirus Pandemic event will be discussed and analyzed. The instruments of photography, intended as tools of representation will be applied to this specific environment, then used as a base of reflection about the perception of the changes in the urban environment and the effects of this perception on people. Most of the approaches conducted on social media and the newspapers have pointed to putting in evidence the spectacular empty cities 'as never seen before', which thing is correct and underlines a unique condition otherwise almost impossible to experience. The total lock-down caused by the emergency made it impossible to move from a view of the urban landscape to another, where most of the people were able to see such an emptiness only for their town, maybe just for their neighbourhood and maybe just from some lucky windows. The global condition will be watched not simply by composing together the pictures exhibited online and in the newspaper, but using a specific set of images, created in the days of the emergency that will comment and describe the contents of the article.
\end{abstract}

\section{Keywords}

Pandemic, Photography, Emptiness, Representation, New Coronavirus. 


\section{Introduction}

With the spreading of the New Coronavirus Epidemic event in March 2020 the need for strong safety measures to limit the diffusion of the Virus came out as a mandatory priority for all the people: in between the various measures, two of the most and relevant in the tentative to contain the contagions were the self-isolation, established following a series of specific laws and temporary rules connected to the general lockdown.

The choice for self-isolation was quite mandatory, especially during the first wave of the contagions, first of all, because it was the safer solution while the real entity of the pandemic event was going to be understood and people and institutions/administrations were going to learn how to protect themselves efficiently. Self-isolation was as well a way to have time to equip the whole country, in fact, the second measure, the use of facemasks (named most of the time simply 'mask' or 'little masks' -mascherine-), turned out to be quite complex, while in Italy, at first, the supply for the masks was quite problematic, with various issues in the delivery (Tarquini, 2020), production (Savelli, 2020), organization and several "black market" and inflated prices (Lombardo, 2020). The story of the pandemic event reconstructed at now started about the end of 2019: from the 31 December 2019, Chinese au- thorities informed the WHO (World Health Organization) China office of pneumonia cases in Wuhan City, Hubei province, China, with an unknown cause'. After 22 January 2020 WHO confirmed human-to-human transmission of the virus².

With the gradual spreading of the epidemic out of China, Italy was at the beginning the most afflicted country, with a rapid diffusion in the Northern part of the national territory and high rates of contagions and deaths. In the period between the beginning of March and May 2020, the following guidelines of the Italian Ministero della Salute ${ }^{3}$ defined a series of measures to stem the diffusion of the virus, with the use of masks, accurate cleaning and self-isolation as main personal and collective strategies against the Virus.

The COVID-19, the 'COVID', soon became a wellknown and continuously used word. Italy was one of the first countries in Europe to receive the impact of the virus. Following the Ministerial Decree of the 8th of March 2020, the Italian Government imposed great restrictions, making the whole of Italy a red zone, not only people's lives changed but also places apparently changed in their nature: deprived of their relationship with people they lost their aggregative, social and practical function.

The state of "Pandemic" was declared on the 12th of March $2020^{4}$. Pandemic events have affected 
creased of almost five times in one century.

In this context, the needs caused by the lockdowns operated as accelerators of certain ongoing processes, like the "online teaching" (Mishra, Gupta, Shree, 2020), the "smart-working", the "online communities", the "dematerialization of social relationships" (de Rosa, Mannarini, 2021), the online shopping, the online migration of functions and services and the use of "online entertainment" (Koeze, Popper, 2020). In Italy, the first lock-down took place from the 9 th of March to the 4th of May 2020, in this period most of the population observed quite strictly the rules of self-isolation, remaining in their houses and limiting their activities just to the nearby areas.

The uncertainty of the situation at that time, the rigid rules aimed to contain the contagions and the general fear about what was going to be played together in reducing to a minimum the interaction with the world outside.

At the moment of the initial lockdown, the scenario about what was going to happen was uncertain, but the effects on the local economy (Ascani, Faggian, Montresor, 2020), the limitation in personal freedom (Jovičić, 2021), the effects on psychological health (Orbach, 2020) and the social crisis (Lupton,

\section{Communication choices}

The newspapers and social media described the pandemic event from various points of view, keeping people updated, giving it a real dramatic tint and sometimes bringing to the extreme certain aspects of the situation (O'Hair, 2021). Some elements became iconic with ease, all the major differences caused by the lock-down were underlined and presented, often redundantly. While the spreading of the Virus in Europe was manifest starting from Italy, the main historical cities, considered worldwide a place of beauty and arts, received immediately the impact of the 'abandon' by the tourism soon followed by the effects of the full lockdown, passing from beautiful crowded places (Fig.1) to beautiful empty places.

The emptiness of the main urban centres was one of the 'classic' and more impacting types of image (or video) presenting the new urban situation.

It is now worth noticing the three components that caused the 'emptiness', which is a quite particular event even for a recursive event like a pandemic. The first operator in the alchemy bringing to the deprivation of people from the urban scenario was the lock-down in itself, people were forced to stay in their houses by rules, self-choice, or fear. The second operator was the interruption of travelling and the touristic visits. The third was moving to digital platforms all the activities compliant with online solutions. In this situation, 'the emptiness' was extremely relevant in the downtowns, especially in the 'cities of art' where citizens are reduced to a minimum in place of temporary touristic residences, shops, offices, services and cultural structures, creating environments with situations where no one had any longer reason to go if not for admiring the emptiness or the monuments deprived of the 'noise' caused by humanity. But the imposed rules were so strictly limiting the movement of people that the observing of such a situation was restricted to online images and videos. 

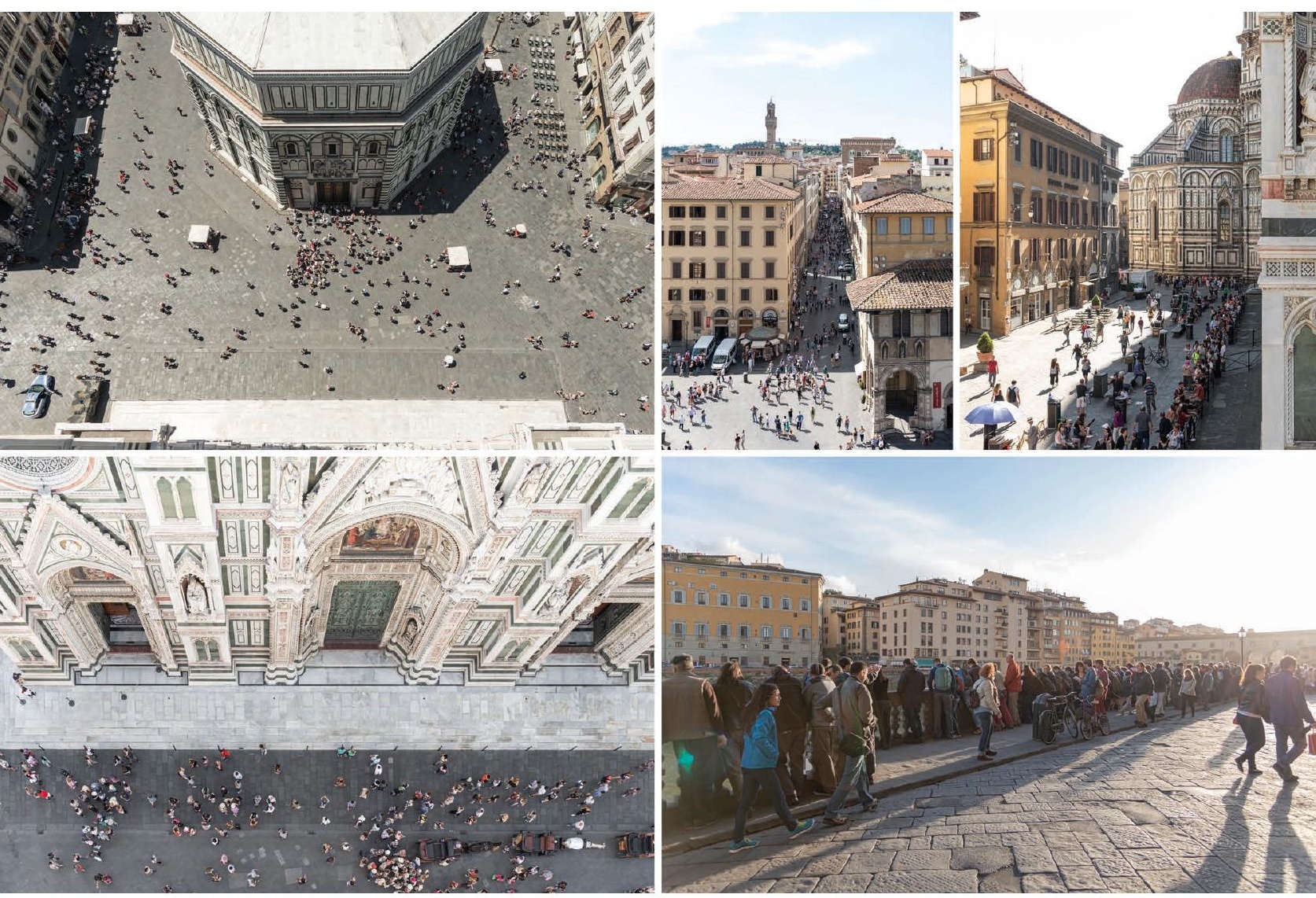

Fig. 1 - Pictures from the Florence town centre in its common crowded condition before the lockdown (Photos by S. Giraudeau, 2018).

For a large number of people even if living in Florence or Venice or Rome, etc., for them, the image of the 'emptiness' was just the one of their neighbourhood, with minimal options for visiting the downtowns. In these contexts, the impression of the 'emptiness' was more a perceptive phenomenon than a real condition.

The crowding, produced by the tourists, disappeared, but the people living in the city were not that far.

The people were not really 'away', they were in the houses, coming out only at real needs, working, studying and having their free time in the inside of the flats, mostly in front of a computer or other personal devices.

\section{Describing Florence in pictures}

Photography is art and technique of representation, the apparently 'abandoned' and empty urban landscape of Florence appeared since the first days of lock-down a complex subject, easy to be just 'represented' but in need of documenting a specific emphasis. It appeared immediately as a very interesting research subject for survey and representation, perfectly balanced between the need for gathering images of a specific historical moment and capturing a city in its 'perfect emptiness' moment. The effects of such an unlucky event were creating the ideal situation for taking images of monumental places otherwise crowded. From March to May 2020 , to document the conditions of the downtown 


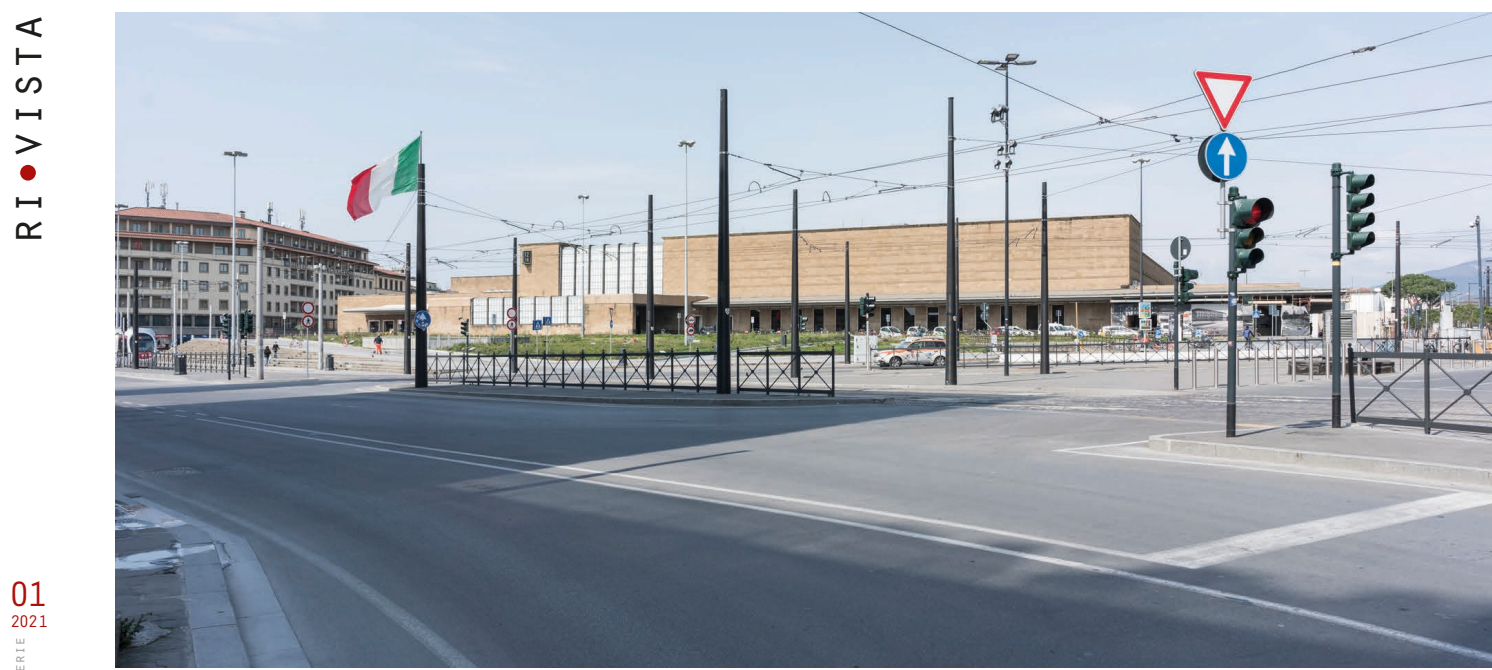

Fig. 2 - Florence town centre, Santa Maria Novella Railway Station (Photo by S. Giraudeau, 2020).

in Florence, a specific photographic campaign took place. The Laboratorio Fotografico Architettura (Architecture Photographic Laboratory, LFA) from the Dipartimento di Architettura (DIDA) of the University of Florence, developed a specific operative plan of documentation, it was organized in a series of strategic choices, structured around some main focal points and monuments in the Florentine town centre (Figg. 2-18, 21).

During the lockdown period, between March and May 2020, it was not possible to move except with special permits; consequently, to move around the city of Florence to carry out the documentation activity, it was necessary, in addition to the self-certification documents. So, a series of specific authorizations were produced to support the activities, these documents have been fundamental during the frequent controls of the police to attest the tasks creating the necessity of a presence in the city.

The meeting with the 'empty' Florence was of great strength: those spaces full of life sometimes even suffocated by mass tourism appeared suddenly emptied, telling a different story and showing a very uncommon aspect. The difficult and unhap- to observe and narrate the buildings, squares and monuments, with a reversal vision of the city. This survey project aims to change the narrative of the city of Florence by focusing exclusively on the aesthetics of space and architecture, favouring a purely architectural photographic language.

Two frames to tell each subject: the aerial point of view, through zenithal planimetry that frames the architectural subjects, allows having a clear view of the urban fabric appreciating the geometry without, almost totally, the presence of man. From the ground instead, the 'typical' point of view and the wide framing give us a reading of the environmental context in which the building is inserted.

The photographic survey work was divided into two major parts (Fig. 19). All aimed at producing high-quality contents and operated according to rules of urban photography reportage (Cornbill, 2019) adapted to the need of a specific case, a 'suspended' (or interrupted) city, and then somehow passing by the habits of the "Urban exploration" (Sipes, 2014). A process that would have to consider the 'emptiness' without turning it to be a portrait of the city in a perfectly clean condition, the concept was to transmit the impression of 'something im- 


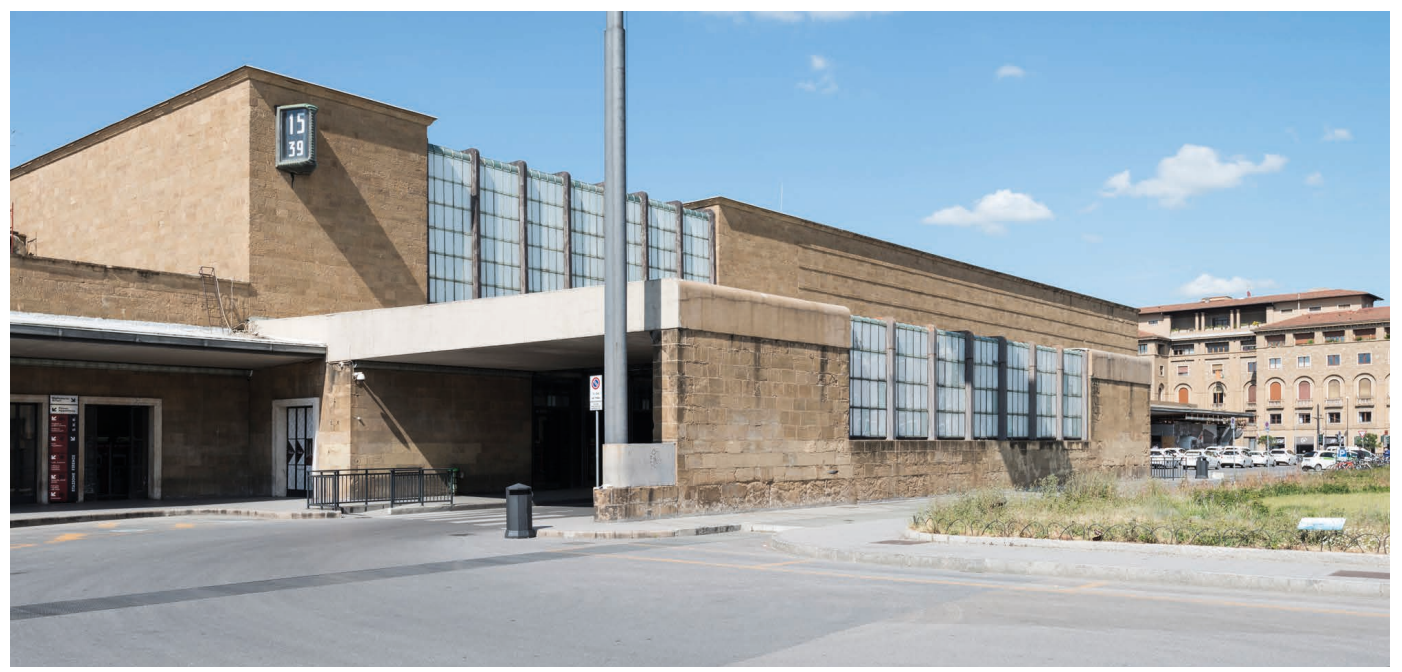

Fig. 3 - Florence town centre, Santa Maria Novella Railway Station (Photo by S. Giraudeau, 2020).

portant is missing' even when the crowded areas were until them, a despicable situation for an architecture photographer or surveyor.

The first part was the photographic campaign from the ground that took place from March 17th to April 27th with a production of 306 post-produced images and a hundred video shots.

The cameras used for these operations were a Nikon D800, Full Frame, 36MP and a Sony Alpha 7RII, Full Frame, 42.4MP. The first was used with a tripod, to make, in addition to photos, also video footage (1080 Full HD) while the second with a fixed lens $(28 \mathrm{~mm}$, F2.0) was used freehand. The Nikon 0800 was equipped with the following lenses: $16-35 \mathrm{~mm}$ F4.0 Nikkor, 24-120mm F4.0 Nikkor, 35mm F1.8 Nikkor.

The second part was the aerial photographic campaign that took place from May 1st to 17th with a production of 20 post-produced images and about fifty video shots ${ }^{5}$ (taken at the resolution of $4 \mathrm{~K}$, 4096x2160). These operations were conducted using a Parrot Anafi UAV/Drone with a 1/2.4" Sony sensor, $21 \mathrm{Mp} C$ mos and a fixed wide-angle lens F2.4 ASPH (Focal length (35mm format equivalent): 23-69mm for photos, $26-78 \mathrm{~mm}$ for videos) ${ }^{6}$. Italian and European regulations on the use of a UAV (Un- manned Aerial Vehicle) are very stringent and limit the use of drones depending on their weight and the context in which they are used. Without going into the regulations, to fly a drone of a certain weight, in addition to having a flight license and insurance, one must apply for special permits issued by ENAC and ENAV, air traffic control bodies (ENAC, 2019). To facilitate the resolution of this problem you can opt for the choice of lighter drones, with fewer regulatory constraints.

Given all these parameters to be taken into consideration, for the documentation of Florence during the lockdown, a drone lightened from 320 grams to 300 grams was used to be able to operate in urban contexts with non-critical operations, as required by Italian aviation regulations ${ }^{7}$. For each flight operation (five missions in all) a communication was made with a PEC-mail to both the Police Headquarters and the Prefecture of Florence to have confirmation of the possibility to fly on the agreed days. The flight operations were carried out with the utmost safety and planned to be able to carry out the filming in the best and quickest way possible (a good rule of flight safety is that the operations should last as little time as possible). 

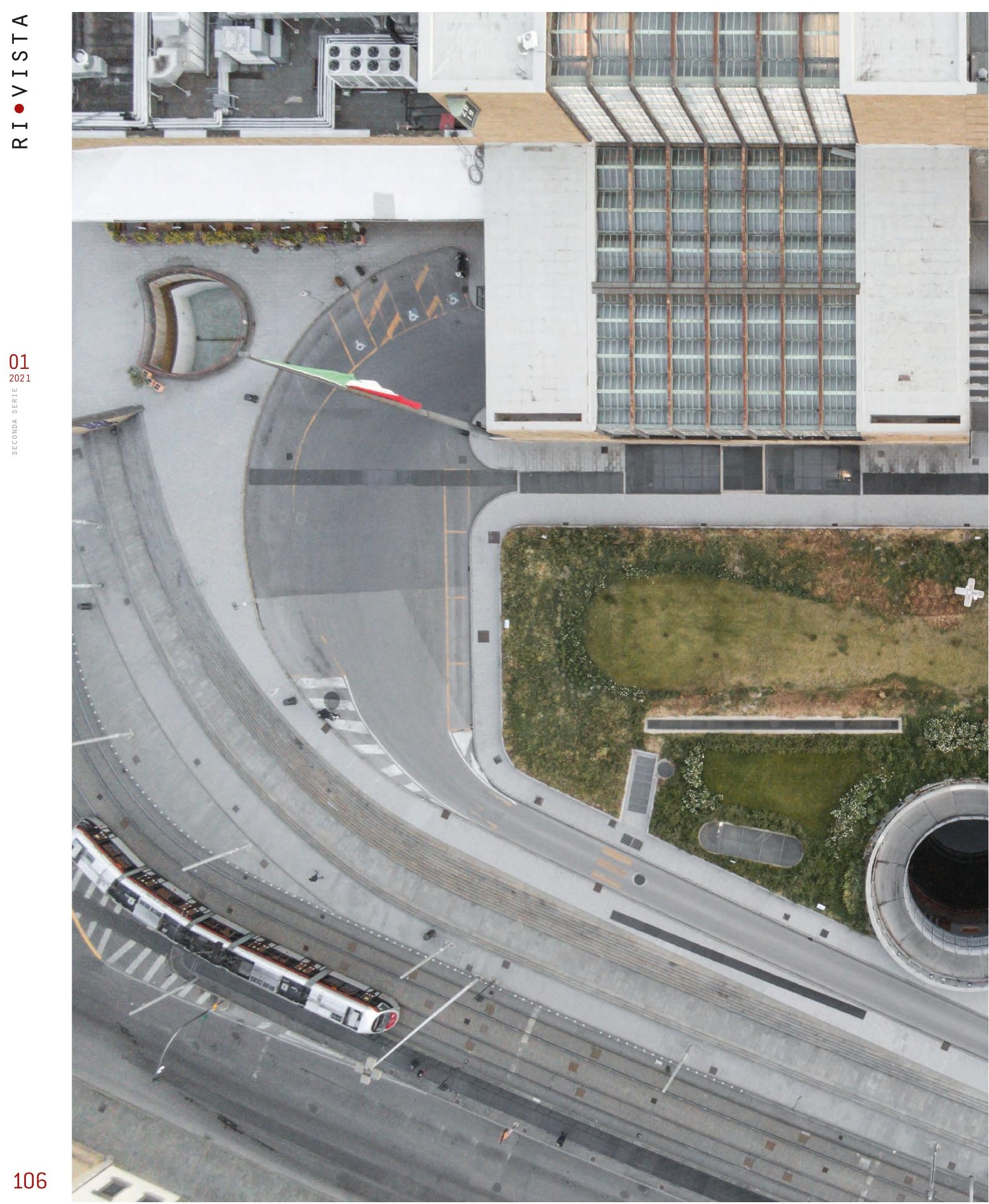

Fig. 4 - Florence town centre, Santa Maria Novella Railway Station (Photo by S. Giraudeau, 2020). 

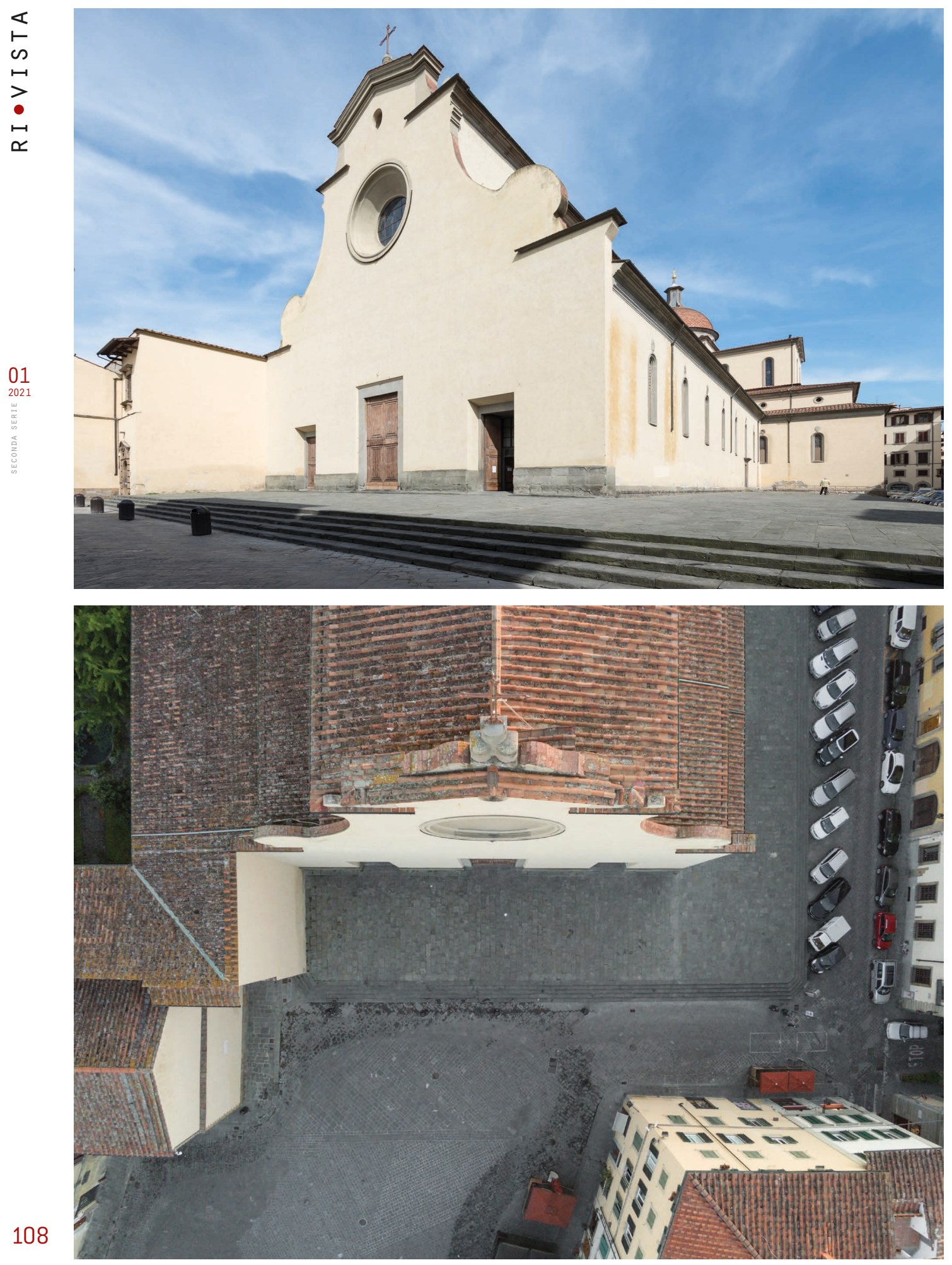

Figg. 5-6 - Florence town centre, Santo Spirito (Photo by S. Giraudeau, 2020). 

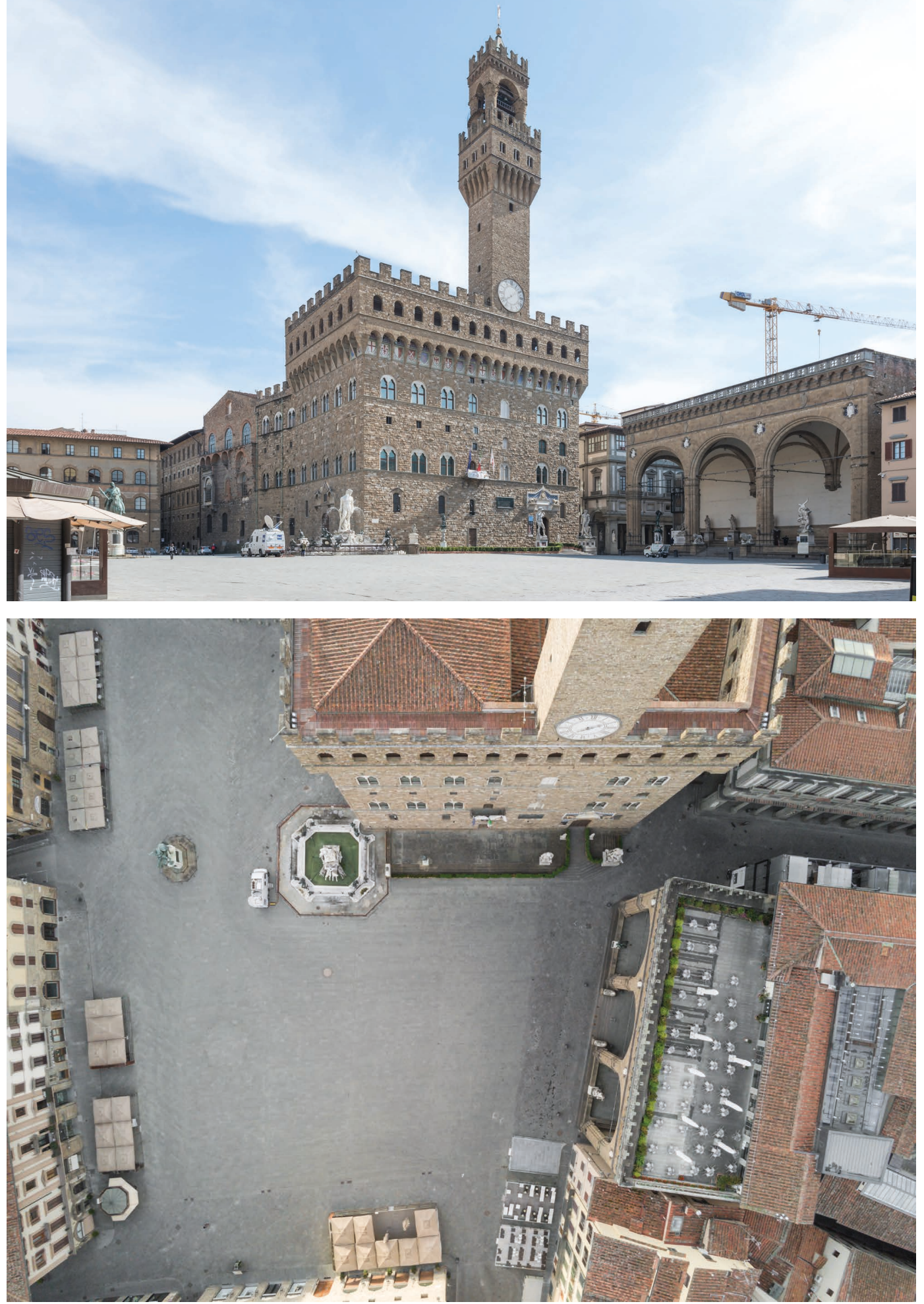

Figg. 7-8 -Florence town centre, Palazzo Vecchio (Photo by S. Giraudeau, 2020). 


$\varangle$
$\bullet$
$\infty$
$\mapsto$
$>$
$\bullet$
$\ddot{\simeq}$
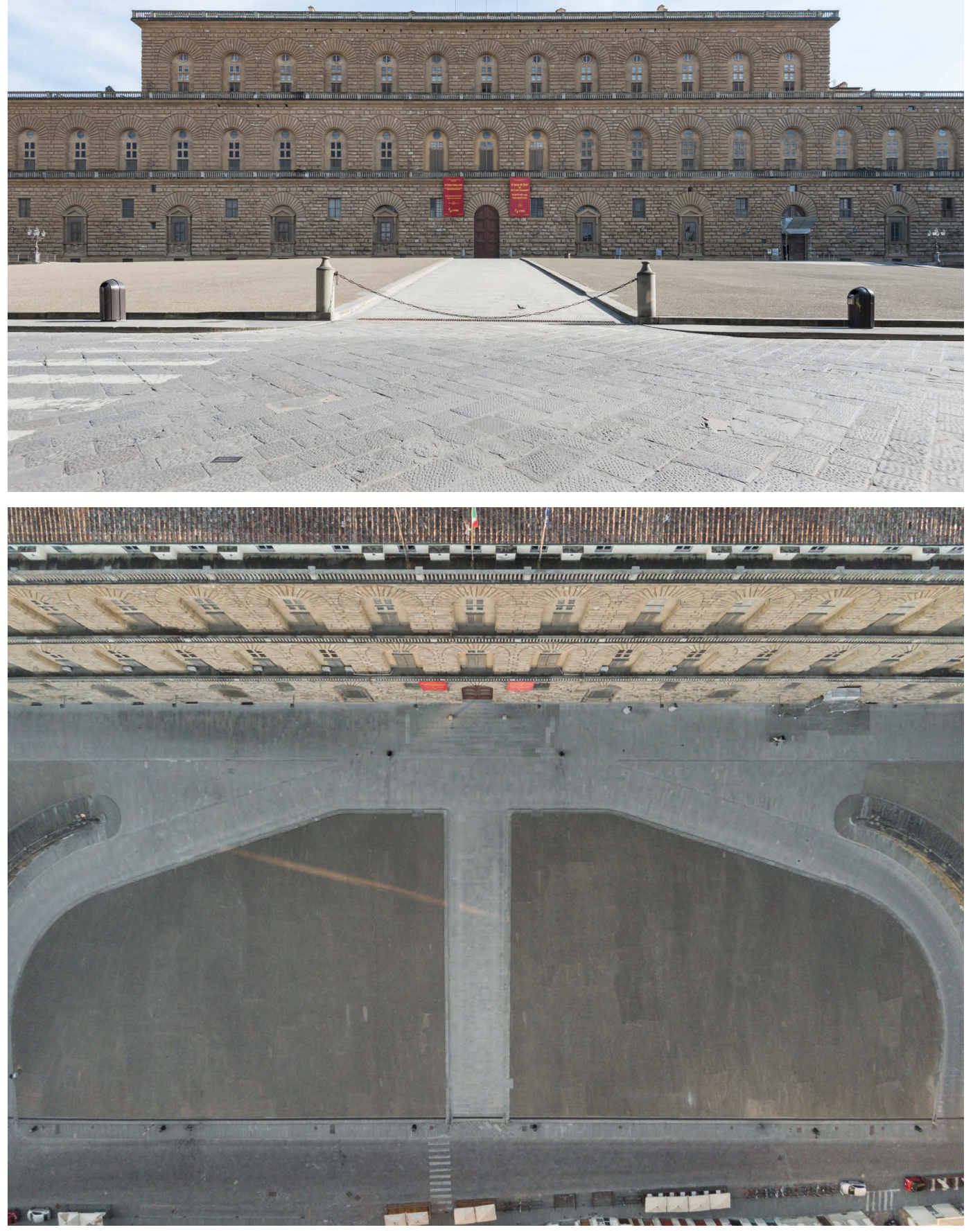

Figg. 9-12 - Florence town centre, Palazzo Pitti and Ponte Vecchio (Photo by S. Giraudeau, 2020) 

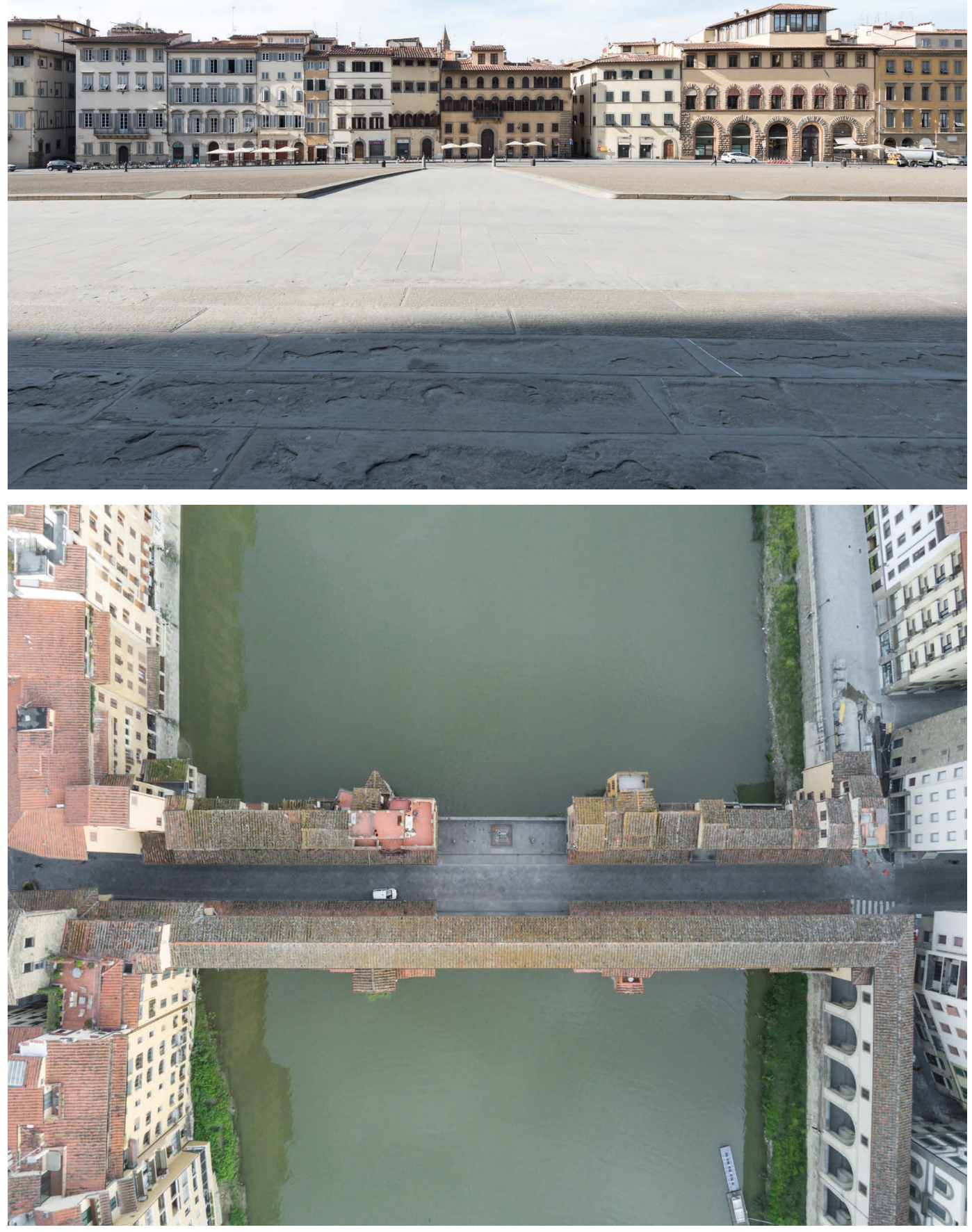

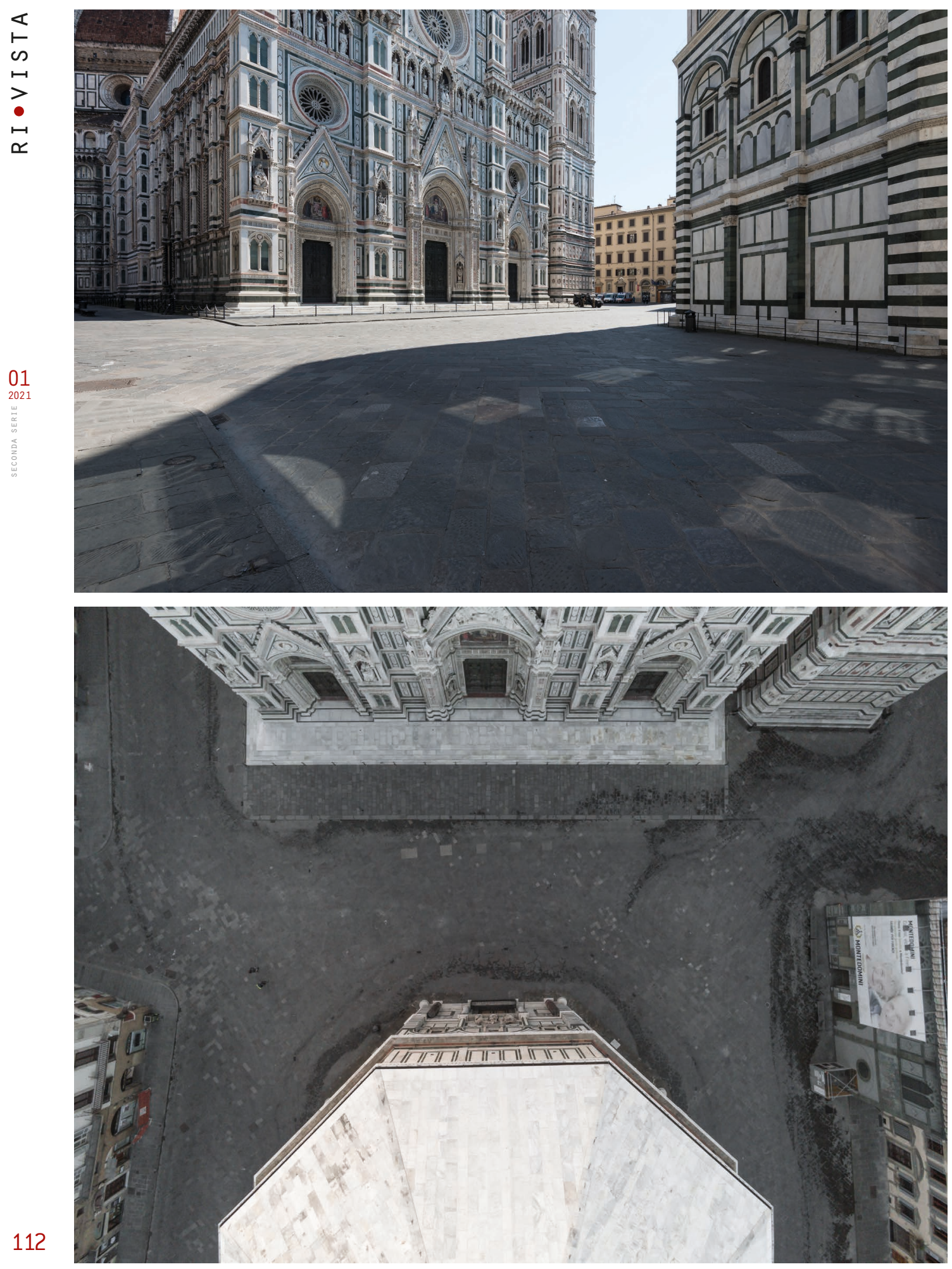

Figg. 13-14 - Florence town centre, the Cathedral and the Baptistery (Photo by S. Giraudeau, 2020). 


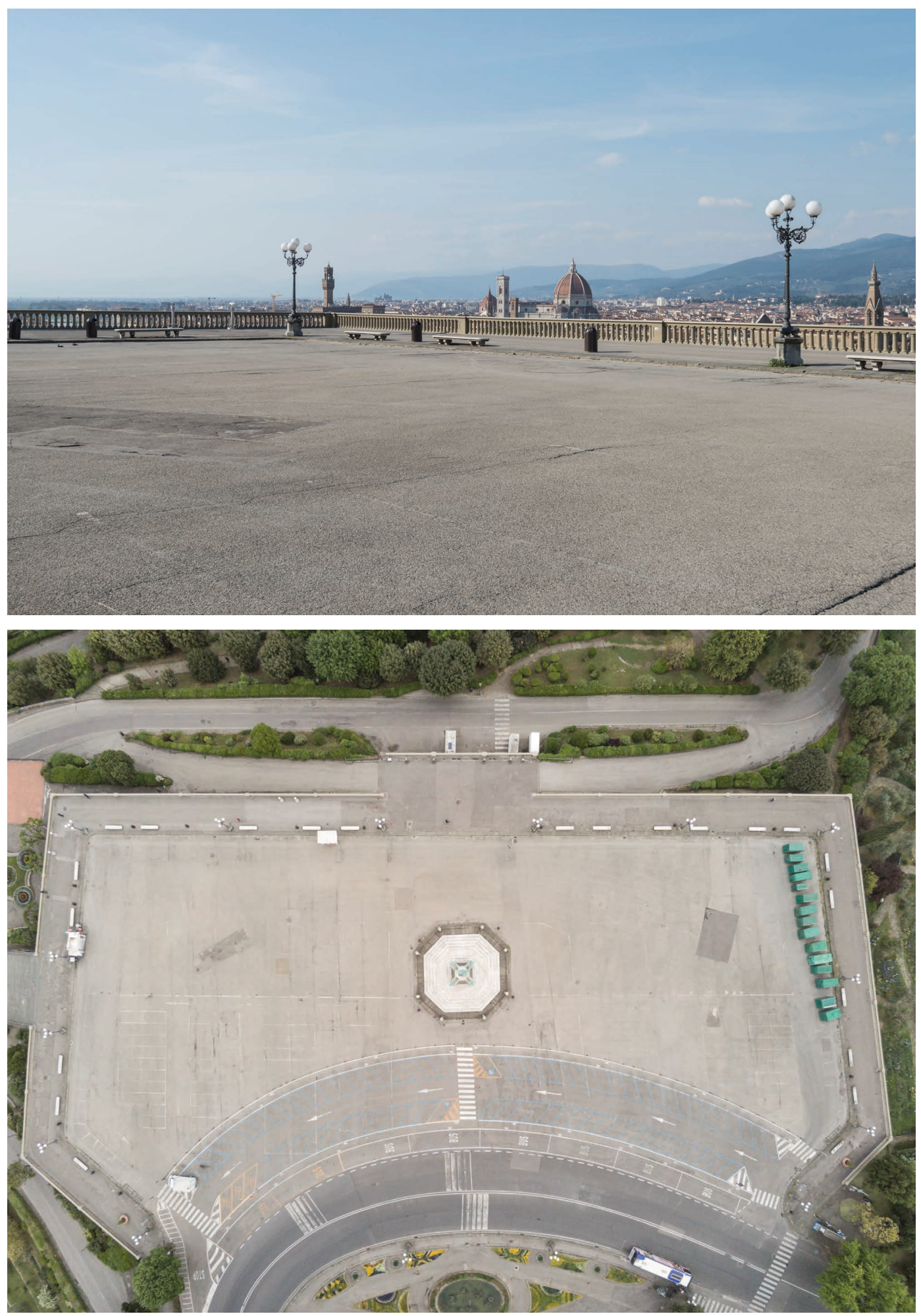




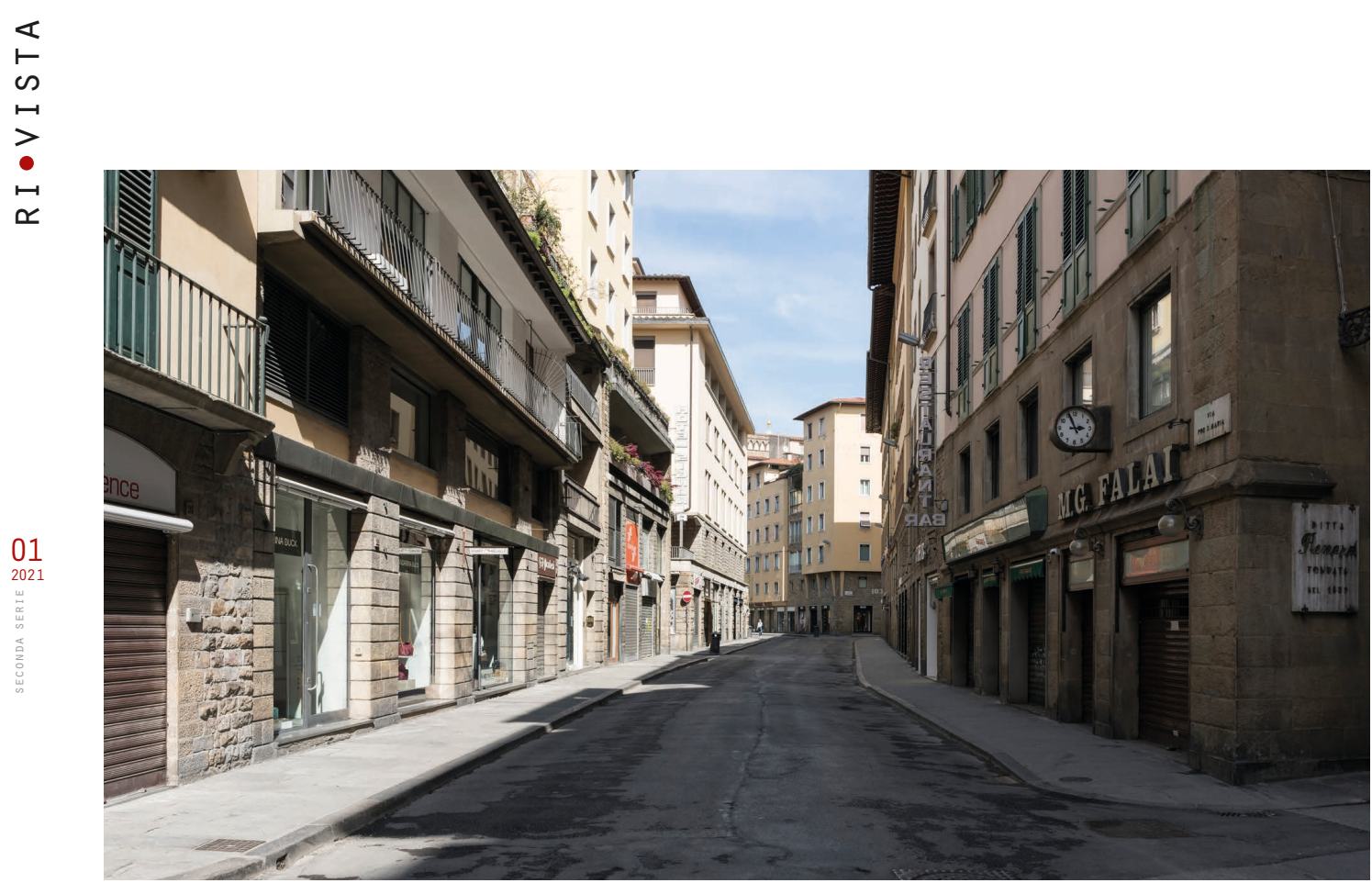

Fig. 17 - Florence town centre, nearby Ponte Vecchio (Photo by S. Giraudeau, 2020).

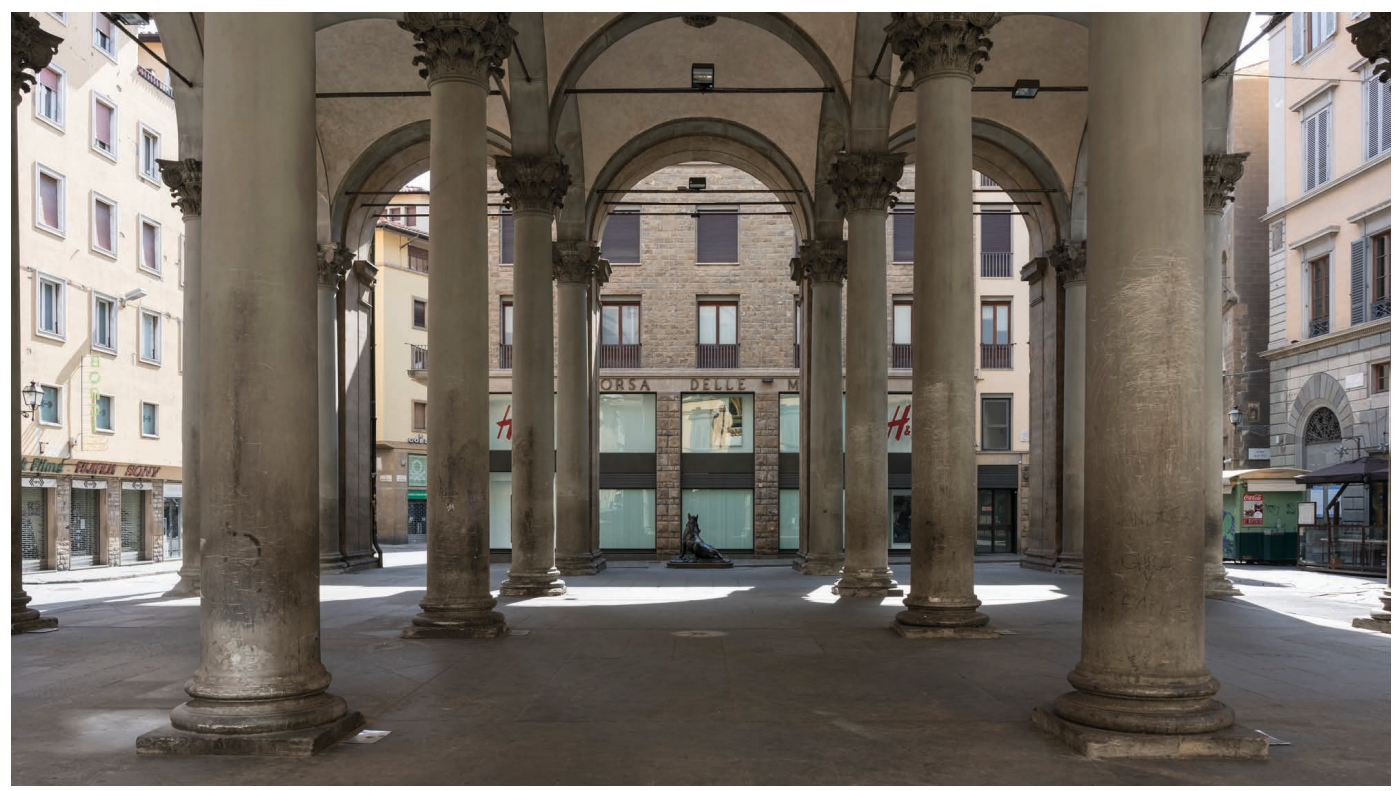

Fig. 18 - Florence town centre, Loggia del Mercato Nuovo (Photo by S. Giraudeau, 2020). 

6. 65.

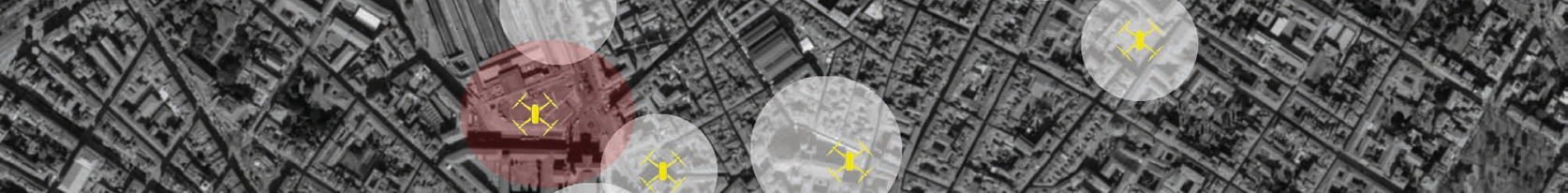

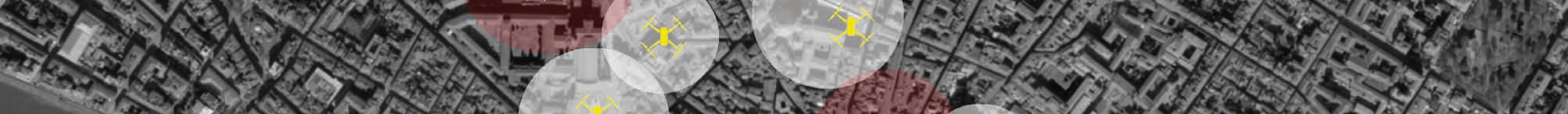
m.5. 1.14.

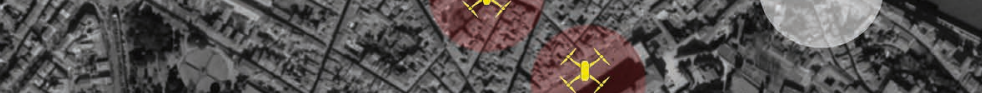

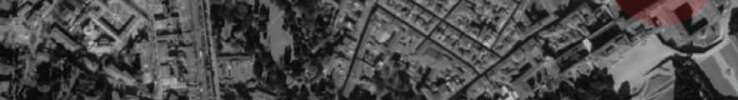

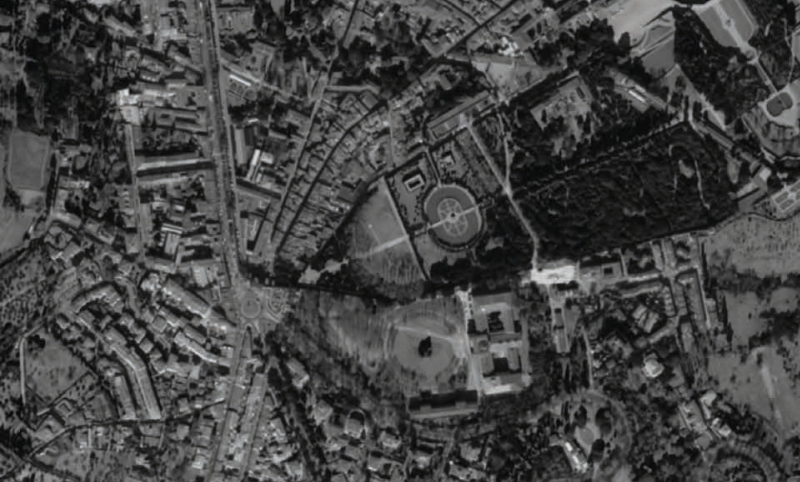

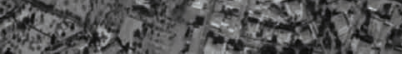

Fig. 19 - Map of the aerial and ground photographic sessions

(orthophoto by Regione Toscana, Geoportale, graphic by the authors, 2020). 

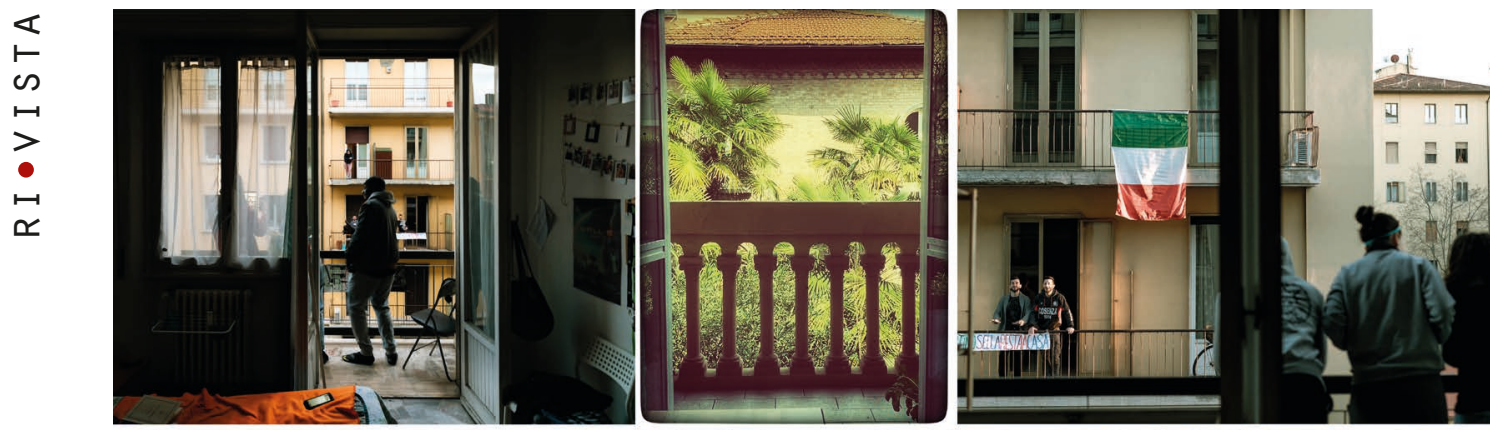

01
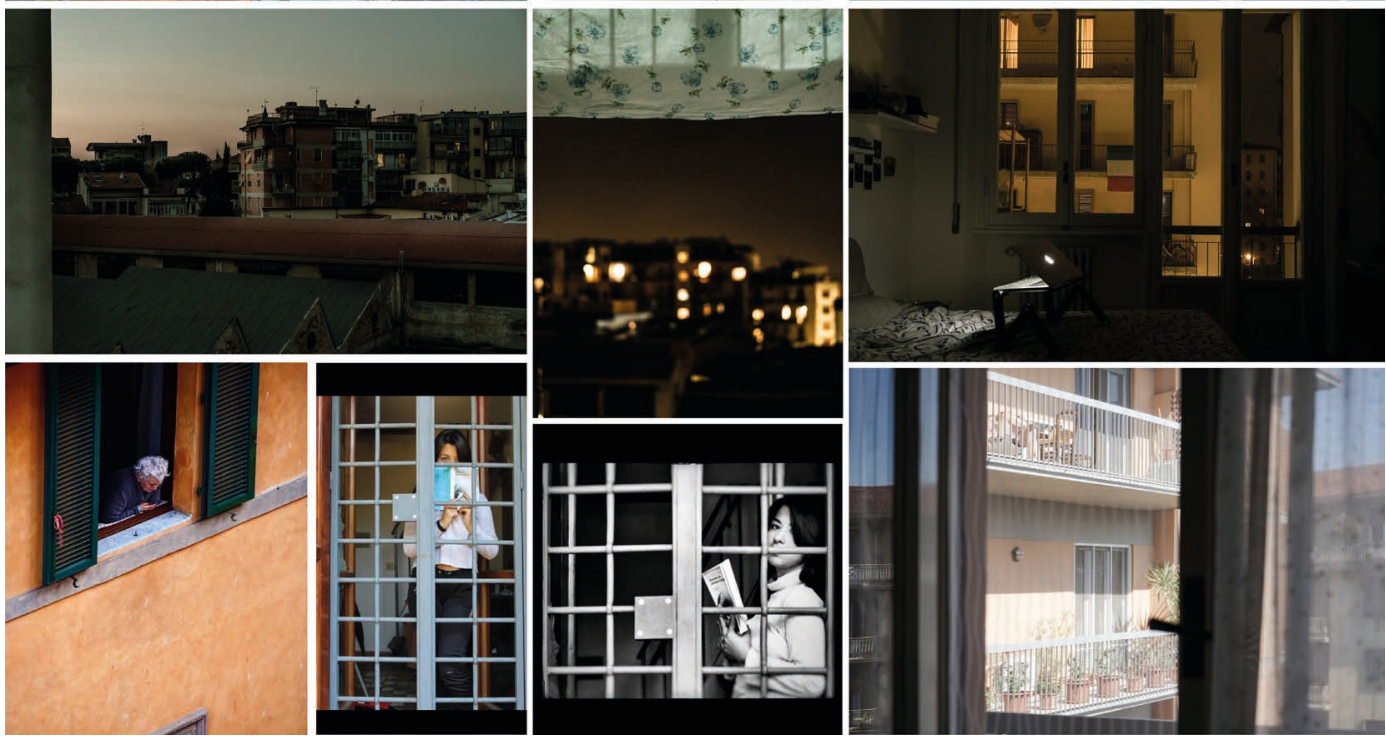

Fig. 20 - March-April 2020, from the inside to the outward

(pictures by Dario Borruto, Caterina Olivadese, Andrea Bottazzi, Piera Morreale, Francesco Maria Martella)

\section{The perception of the town from inside the houses}

Florentines and all the people somehow blocked in Florence experienced the long period of the first lockdown from their houses, they rarely went out and spent most of the time using social media and online news to get information about the ongoing situation. This condition was common all around Italy, it was previously experienced in China and all across 2020 was going to be quite common worldwide with various declinations. For all the people in lockdown, the access to online media was fundamental: news, updates, rules, details and information about spontaneous way, searching specific information and then going back to that same websites or in an 'accidental' way, receiving information from social networks, mixed with many others or 'inside' posts, the whole world in few weeks was going to orient all its attention to one main argument: the pandemic and its effects on the 'past' usual context.

The heavy reduction of mobility pushed the sense of community coming from being all in a similar situation and it brought towards common behaviours and to the sharing of experiences by social networks. As stated a few lines above, the perception of the empty state of the town was mostly linked 

people living every day in the town or just blocked there at the moment of the lock-down are inside their houses. But at the same time, thinking back to the period of the first lock-down in Italy, it may be recognized how the altered condition of urban and social living has brought some weird effect in the perception of the time, the emptiness seems to affect time in the "Taoist concept" of "void time" (Pasqualotto, 2004) where the balance between the "what has been" (belonging to a time gone and past) and "what it will be" (belonging to an unpredictable future) creates an emptiness. During the lock-down, with people forced to stay at home and maintain isolation rules, this 'empty time' seems mostly capable in capturing desires and aspirations: desires about having back the past conditions and aspirations about getting out from the present limitations and difficulties, somehow a nullification of the present, sometimes bringing to an early reaction, but on the long run causing laziness, inactivity, unhealthy behaviours.

This altered perception of time may be found in almost anyone experiences from the past year and has received various studies (Ogden, 2020), mixed towns, recalling some robust cultural references, from the oniric spaces depicted by Giorgio De Chirico (Calvesi, Mori, 1998) to the "Urban Void" filmed in certain movie sequences by Michelangelo Antonioni (Pascal Bonitzer, 1983).

This condition was fixed in the mind of all the people watching them with two main different reactions: the feelings associated with the perception of what is missing, of the absence of people, versus the pure perception of the urban and architectural landscape cleaned from any noise caused by the crowd and traffic.

In a way the 'look how it is empty' against the 'look how it is free', someone noticing mostly what is missing, someone noticing mostly what is present, maybe someone has a perception of both the aspects.

The results from this urban photography reportage try to fix this contents and sensations, freezing a moment, a pause in the flight of the drone or a breath of the photographer, leaving the emptiness of the space flowing, trying to transmit the impression that even out of the frame, all around who was taking that picture there was the same persistence of isolation.

\section{Conclusions}

The weird, difficult and dramatic long pandemic event will leave a deep mark in society, probably something the most will prefer to forget and put away in what it will be in general remembered for being a 'horrible year', thus all along the period of the lock-downs the debate and discussion about the future was well present, from the approach to Cultural Heritage (Lovino, Migaleddu, Pescarmona, 2020) to the hypothesis about next architectures (Bahadursingh, 2020; Giacobbe, 2020; Schneider, 2020). Something very appreciable in a period that may seem not the 'right time' for architects, urban planners, cultural heritage experts, landscape designers. It is possible to argue that there are some lessons learned from the whole pandemic event and 
the balance between the 'new' needs and urban/architectural design/approach. One is that the massive exploitation of social spaces and built heritage is something that works exactly against keeping active the functions planned for that same place.

The overcrowded downtowns, the urban public areas filled with restaurants and food/touristic market-related functions, the railway stations saturated with shops, overloaded museums with cues, pubs and shops finding places inside the urban tissue, are often planned merely according to a market logic that seems to consider hygienic and healthy planning as a limitation to their possibilities more than a needed set of good rules for good living, obviously, they obey to safety rules, which means that no one is at risk in case of fire or rapid escape, but they are no elastic at all in front of social distancing, nor for a pandemic event, neither for very simpler contagions casualties.

There is now a new altered balance between what it is possible to do for having most of the profit and the logic (and 'taste') about what it is worth to do for keeping a place versatile and coherent with its architectural 'nature'. It seems obvious that the people for first will push for going back to the previous conditions, seeing habits that were not that good either before the pandemic event like something desirable in front of the isolation and bad times caused by this disaster. The urban reportage from March-May 2020 is then a possible useful document for reminding the effect of the emptiness and the imposed 'perfection' arrived all over the downtowns something probably and hopefully impossible to reply.

All the next pictures of the Florentine downtown will need to be taken very early in the morning, retouching the persons around, using neutral density filters to extend the exposure time and making them disappear like in an old picture taken with poorly sensible photographic materials. But the option for taking that emptiness, that sensation of 'retreated humanity' is reserved to that specific moment.
The pictures taken at that right time should be observed, they may evoke that moment, that surprise and rise a reflection about what means a 'city of the arts' deprived of its visitors, a town rich of arts and museums with closed doors and an urban space brought back to its silent essence. At the same time, this reportage is ready to take part in the large collection of iconic images of the 'emptiness' taken worldwide and ready to enter the archive of this period, a long series of iconic moments where 'nothing was happening while everything was happening', ready to fill the time gap between the past and the future and to support a future that will be claiming the return to past behaviours, no matter how wrong or helping the last virus spreading they were. 
01

2021

\section{Endnotes}

${ }^{1}<$ https://www.who.int/news-room/detail/08-04-2020who-timeline---covid-19> (03/21)

${ }^{2}<$ https://www.who.int/china/news/detail/22-01-2020field-visit-wuhan-china-jan-2020>(03/21)

${ }^{3}<$ http://www.salute.gov.it/imgs/C_17_pubblicazioni_501_allegato.pdf> (03/21)

${ }^{4}<$ http://www.euro.who.int/en/health-topics / health-emergencies/coronavirus-covid/news/outbreak-pandemic > (03/21)

${ }^{5} \mathrm{~A}$ video version of the shooting is available in the Vimeo platform at<https://vimeo.com/496091986>.

${ }^{6} \mathrm{All}$ the cameras in use are property of the DIDALABS System, except the Anafi Parrot Drone/UAV, owned and registered by Stéphane Giraudeau.

${ }^{7}$ Art.12. Comma 5: "Le operazioni condotte con APR di massa al decollo minore o uguale a $0,3 \mathrm{~kg}$ con parti rotanti protette da impatto accidentale e con velocità massima minore o uguale a $60 \mathrm{~km} / \mathrm{h}$, fermo restando quanto previsto al comma 2 del presente articolo, sono considerate non critiche in tutti gli scenari operativi. II pilota deve conseguire l'Attestato, secondo quanto previsto al successivo articolo 21, entro il $1^{\circ}$ luglio 2020."

\section{References}

Ascani A., Faggian A., Montresor S. 2020, The geography of COVID-19 and the structure of local economies: The case of Italy, in «Journal of Regional Science», Vol. 61, n.2, pp. 407-441, Wiley Periodicals LLC.

Bahadursingh N. 2020, 8 Ways COVID-19 Will Change Architecture, in «Architizer Journal», $31 \mathrm{Dec},<$ https://architizer.com/blog/inspiration/industry/covid19-city-design/> (03/21), USA.

Bonitzer P. 1983, I/ concetto di scomparsa, in Fink G., Bernagozzi G., Michelangelo Antonioni: Identificazione di un autore, Pratiche Editore, Italy, pp.147-150.

Calvesi M., Mori G. 1998, De Chirico, Giunti Editore, Italy. Cornbill T. 2019, Urban Photography, Gribaudo editore, Italy.

de Rosa A. S., Mannarini T. 2021, Covid-19 as an "invisible other" and socio-spatial distancing within a one-metre individual bubble, in «Urban Design International», Springer Nature, UK.

ENAC 2019, Regolamento mezzi aerei a pilotaggio remoto, Art.12 C. 5. Ed. 3 11/11/19, <https://www.enac.gov.it/ la-normativa/normativa-enac/regolamenti/regolamenti-ad-hoc/regolamento-mezzi-aerei-pilotaggio-remoto> (03/21), Italy.

Giacobbe A. 2020, How the COVID-19 Pandemic Will Change the Built Environment, in «AD, Architectural Digest magazine» 18/03/2020, <https://www. architecturaldigest.com/story/covid-19-design> (03/21), USA.

Jovičić, S. 2021, COVID-19 restrictions on human rights in the light of the case-law of the European Court of Human Rights, in «ERA Forum 21», pp. 545-560, Springer Nature, UK.

Koeze E., Popper N. 2020, The Virus Changed the Way We Internet, in «The New York Times», 07/04/2020, USA. 
Lombardo I. 2020, Mascherine, anche la Cina è un problema: ritardi, pochi certificati e prezzi alle stelle, in «La Stampa», 06/04/2020, GNN-GEDI gruppo editoriale S.p.A., Italy.

Lovino O., Migaleddu S., Pescarmona G. (Ed.) 2020, Per un'altra Firenze: voci sul futuro del nostro patrimonio, Firenze University Press, Italy.

Lupton D., Willis K. 2021, The COVID-19 Crisis, Social Perspectives, Routledge Taylor and Francis, UK.

McMillen C. W. 2016, Pandemics, A Very Short Introduction, Oxford University Press, Gosport, Hants, UK.

Mishra L., Gupta T., Shree A. 2020, Online teaching-learning in higher education during lockdown period of COVID-19 pandemic, in «International Journal of Educational Research Open», Vol. 1, ISSN 2666-3740, <https://doi. org/10.1016/j.ijedro.2020.100012>, Elsevier.

Martin P. 2020, II vuoto non esiste, nemmeno al tempo del Covid-19, in «La Stampa», 18 Marzo 2020, Italy.

O'Hair H. D., O'Hair M. G. (Ed.) 2021, Communicating Science in Times of Crisis: COVID-19 Pandemic, Wiley Blackwell Pub, USA.

Ogden R. S. 2020, The passage of time during the UK Covid-19 lockdown, in «PLoS ONE» 15(7): e0235871. <https://doi.org/10.1371/journal.pone.0235871>, Nishi A. (Ed.), UCLA Fielding School of Public Health, USA.

Orbach S. (2020), Patterns of pain: what Covid-19 can teach us about how to be human, in «The Guardian», 7 May 2020, The long read, UK.

Pasqualotto G. 2004, Estetica del vuoto. Arte e meditazione nelle culture d'Oriente, Ed. Marsilio, Venezia, Italy.

Savelli F. 2020, Coronavirus, chi produce le mascherine e l'alcol disinfettante, in "Corriere della Sera», 19 March 2020, RCS MediaGroup S.p.A., Italy.
Schneider A. 2020, Perkins + Will on the Strategic Elements of Post-Pandemic Workplace Design, in «ArchDai|y», <https://www.archdaily.com/953518/perkins-pluswill-on-the-strategic-elements-of-post-pandemic-workplace-design> (03/21), USA.

Sipes T. 2014, Urban Exploration Photography, a Guide to Creating and Editing Images of Abandoned Places, Peachpit Press, USA.

Tarquini A. 2020, Coronavirus, mascherine per I'Italia sequestrate dalla Repubblica Ceca, in «La Repubblica», 21/03/20, GEDI Gruppo Editoriale S.p.A., Italy.

Tufekci Z. 2021, 3 Ways the Pandemic Has Made the World Better, in «The Atlantic», https://www.theatlantic.com/ health/archive/2021/03/three-ways-pandemic-has-bettered-world/618320/ (18/03/21), USA. 